\section{RIBEIRO SANCHES E A HISTÓRIA DA MONARQUIA portuguesa}

Ribeiro Sanches and The History of the Portuguese Monarchy ${ }^{1}$

\begin{abstract}
Resumo
O artigo examina como Ribeiro Sanches interpretou a história da monarquia portuguesa do final da Idade Média até a segunda metade do século XVIII, período em que o autor redigiu seus trabalhos. Verifica-se a semelhança de sua produção com as análises ilustradas a respeito de outras monarquias europeias, em especial a francesa, o que permite definir sua obra como uma contribuição para a "história filosófica" das Luzes. Por outro lado, investiga-se em que medida sua análise histórica buscou respostas para os problemas enfrentados pela camada dirigente do Império português. Sendo assim, o presente estudo procura demonstrar como a contribuição de Ribeiro Sanches para a "história filosófica" foi uma tentativa de compreender a suposta decadência portuguesa desde o fim da Renascença.
\end{abstract}

\section{Palavras-chave:}

Ribeiro Sanches, Monarquia Portuguesa, História Filosófica
Luiz Francisco Albuquerque de Miranda

\author{
(1) Ifamiranda@ufsj.edu.br \\ Universidade Federal de São \\ João del Rei \\ São João del Rei, MG, Brasil
}

\begin{abstract}
:
The article examines how Ribeiro Sanches interpreted the history of the Portuguese monarchy from the late Middle Ages until the second half of the 18th century, when the author wrote his works. The similarity of his production is attested to with the illustrated analyzes of other European monarchies, especially that of the French, which permits us to define his work as a contribution to the "philosophical history" of the Enlightenment. On the other hand, we investigate to what extent his historical analysis sought answers to the problems faced by the ruling class of the Portuguese Empire. Therefore, the present study aims to demonstrate how Ribeiro Sanches' contribution to "philosophical history" was an attempt to understand the supposed Portuguese decadence since the end of the Renaissance.
\end{abstract}

\section{Keywords:}

Ribeiro Sanches, Portuguese Monarchy, Philosophical History 


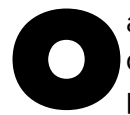
atraso das monarquias ibérica foi tema recorrente da "histórica filosófica" das Luzes. Na terceira versão da História das duas Índias, publicada pela primeira vez em 1780 (utilizo as publicações de Genebra de 1780 e 1781), Raynal identificou a Guerra de Restauração de meados do século XVII como o início da "decadência" da "indústria"² de Portugal. Para conseguir aliados, a Casa dos Bragança concedeu privilégios e vantagens comerciais para outras potências. Esta "precipitação funesta, arruinou seus negócios" e a "indústria portuguesa foi inteiramente massacrada pela concorrência" (RAYNAL, 1781, v. 5, p. 111). A Guerra da Sucessão Espanhola, no começo do século XVIII, aprofundou esse processo, deixando a economia portuguesa nas mãos dos ingleses. Para o autor francês, "é difícil, impossível talvez, que uma nação perca sua agricultura, sua indústria, sem ver decair as artes liberais, as letras, as ciências e todos os bons princípios de política e administração" (RAYNAL, 1781, v. 5, p. 116). A interpretação de Raynal insiste na interdependência entre autonomia econômica e desenvolvimento intelectual. Para ele, nos séculos XVII e XVIII, a monarquia portuguesa "perdeu o fio de seu gênio no esquecimento dos princípios da razão, da moral, da política". É difícil encontrar "bons reformadores" nesse "estado de paralisia e cegueira", pois os homens capazes de transformar os impérios nunca aparecem como "obra do momento". Eles sempre são precedidos por precursores que preparam "os instrumentos necessários para operar as grandes revoluções". Em Portugal, porém, "essa cadeia de meios não parece ter sido formada", a monarquia permaneceu frágil porque jamais adotou os "princípios" das "nações esclarecidas" (RAYNAL, 1781, v. 5, p. 117).

Antes da História das duas Índias, em 1761, na segunda edição de Cramer, o Ensaio sobre os costumes de Voltaire também analisou as debilidades da monarquia lusitana. Segundo o famoso filósofo, contando com o ouro e os diamantes do Brasil, os portugueses "cessaram de cultivar as verdadeiras minas que são a agricultura e as manufaturas". Por outro lado, os recursos obtidos com os metais preciosos eram gastos para comprar as "coisas necessárias que os ingleses Ihes forneciam" (VOLTAIRE, 1963 , v. 2, p. 366-367). Assim, os portugueses tornaram-se dependentes da Inglaterra e não desenvolveram seu próprio sistema produtivo. As riquezas da América pouco contribuíam para seu progresso.

Para Voltaire e Raynal, a decadência lusitana apresentava aspectos econômicos, políticos e intelectuais. A decadência derivava de um conjunto de fatores articulados entre si, indissociáveis, e só poderia encontrar uma resposta eficaz se todos os elementos em causa fossem rearranjados e redefinidos, isto é, se existisse uma ação global orientada pelas Luzes. Mudanças pontuais sem conexões entre si não seriam capazes de reverter o declínio. Era inútil, por exemplo, esperar que um "grande homem" surgisse e transformasse a situação. O progresso só poderia ser retomado com ações graduais que preparassem, lenta e paulatinamente, a recuperação portuguesa.

Essa interpretação da decadência lusitana é uma criação da llustração francesa? Em Portugal não podemos encontrar diagnósticos e reflexões do mesmo gênero? Quem ofereceu aos filósofos franceses os dados para suas análises? 
Nas próximas páginas, tentarei demonstrar como as teses a respeito da decadência portuguesa articulavam-se com o esforço da "história filosófica" das Luzes para compreender como ocorria o declínio das monarquias. Os pensadores franceses foram os participantes mais conhecidos desse empreendimento intelectual, mas alguns autores portugueses também contribuíram para a investigação.

\section{Crítica ilustrada às monarquias}

Em primeiro lugar, convém atentar para o contexto discursivo em que se insere a discussão sobre Portugal no século XVIII: a interpretação ilustrada do regime monárquico. Este era pensado a partir de um conjunto de referências que, a seguir, apresento brevemente.

Mesmo entre os ilustrados mais favoráveis ao "governo monárquico", Franco Venturi encontra o impacto de uma tradição republicana que remonta à Renascença. Segundo o pesquisador italiano, as repúblicas, ainda que debilitadas, sobreviveram nos séculos XVII e XVIII e sugeriam aos contemporâneos um modelo político alternativo. No Espírito das leis, Montesquieu analisa cuidadosamente as repúblicas do período e as compara com o regime monárquico. Para o filósofo, o princípio republicano, desde a Antiguidade, sempre foi a "virtude" (o "amor à pátria") e lhe parece "superior e mais alto" ao princípio que rege as monarquias, a "honra" (o "preconceito de cada pessoa e de cada condição"), pois "coincide com a própria moralidade", "com a capacidade de ditar a si mesmo a própria lei e cumpri-la”. As repúblicas modernas, como as da Itália renascentista, enfrentaram problemas porque a "virtude" foi corroída pela expansão do luxo e pelo crescente poder hereditário de poucas famílias ricas, tornando os regimes vulneráveis ao fechamento oligárquico, ao motim popular ou aos ataques externos (VENTURI, 2003, p. 95-96; cf. também MONTESQUIEU, 1949, t. I, p. 23-33). Segundo o Espírito das leis, quanto "menos luxo há em uma república, mais ela é perfeita"; com o luxo, "o espírito se volta para o interesse particular" e perde o desejo de glorificar a "pátria” (MONTESQUIEU, 1949, t. I, p. 104-105). Assim, quando o desenvolvimento econômico aumenta, possibilitando uma vida luxuosa para parte da população, a monarquia se mostra um regime mais estável e eficaz. Uma república deve ser pequena, pois um grande Estado, com suas enormes fortunas e sujeito a muitas contingências, não é propício à "moderação nos espíritos" e o "bem comum" é esquecido (MONTESQUIEU, 1949, t. I, p. 131). O mérito da monarquia é estabilizar as relações de poder mesmo com a corrosão da "virtude" dos indivíduos.

Partindo de Montesquieu, Venturi procura demonstrar como o "aspecto ético" do republicanismo atraiu os ilustrados:

Embora fora da história ativa e imediata, (...) as ideias republicanas eram ainda capazes de suscitar uma vontade de independência e de virtude que os Estados monárquicos, como explicava Montesquieu, com sua autoridade, em 1748, não estavam em condições de satisfazer. Em meados do século, a palavra república ainda tinha um eco profundo no ânimo de muitos, mas como forma de vida e não como força política. (...) Existia, 
certamente, a moral republicana quando as formas estatais que a haviam acompanhado pareciam antigas e decadentes ruínas. (VENTURI, 2003, p. 140)

Para o autor italiano, um "fermento republicano" animava a reflexão política das Luzes mesmo entre pensadores, como Montesquieu, que reconheciam a ineficácia política das repúblicas na Europa moderna.

Voltaire, muitas vezes associado ao "despotismo esclarecido", também manifestou simpatia pela república. No verbete "Estados, Governos" do Dicionário filosófico, o personagem de um diálogo fictício anuncia que há poucas repúblicas no mundo, pois "os homens são raramente dignos de se governarem por si mesmos", esta era uma "felicidade" restrita aos povos de ilhas e altas montanhas (VOLTAIRE, 1964, p. 181). A simpatia do filósofo aparece de modo mais explícito quando descreve a república dos suíços no Ensaio sobre os costumes: "a igualdade, o quinhão natural dos homens, ainda subsiste na Suíça". Ali, não se observa a "igualdade absurda" que não distingue e nivela os grupos sociais, "mas a igualdade pela qual o cidadão depende apenas das leis e que garante a liberdade dos fracos frente a ambição do mais forte”. A república suíça sempre manteve "a simplicidade, a frugalidade e a modéstia", os atributos indispensáveis para a "liberdade" (VOLTAIRE, 1963, v. 1, p. 666).

A passagem acima atesta como a "igualdade" e a "liberdade" republicanas "fermentaram" o discurso político das Luzes. Voltaire não era republicano, mas encontrou em repúblicas antigas e contemporâneas elementos para a crítica das monarquias. Estas, sem a "igualdade" perante a lei, poderiam assegurar a "liberdade" dos fracos? As hierarquias das monarquias do século XVIII, rigidamente aristocráticas, não favoreciam a "ambição" desmedida dos mais fortes? Eram perguntas fáceis de destilar das páginas do Ensaio sobre os costumes (primeira publicação integral em 1761). Vemos que mesmo filósofos moderados como Voltaire e Montesquieu abordaram as repúblicas de modo a questionar aspectos do regime monárquico. A desigualdade deste último não estava acima de qualquer suspeita. Veremos adiante que essa crítica às hierarquias das sociedades monárquicas reaparece nas obras de alguns portugueses do período.

É importante salientar que os filósofos em tela não propunham, evidentemente, um programa revolucionário. Todavia, sua discreta defesa da igualdade perante a lei e da "liberdade dos fracos" era muito corrosiva para a ordem institucional de reinos como França, Portugal, Espanha ou Áustria. A comparação com a Inglaterra tinha aqui um grande papel, mas não terei espaço para analisar o problema. Assim como não será possível apresentar críticas mais agudas aos regimes monárquicos, como as de Rousseau. Busco apenas salientar que igualdade e liberdade foram as leveduras da fermentação intelectual que possibilitou a crítica às grandes monarquias europeias.

Criticar, porém, não significa recusar a legitimidade das monarquias e negar sua imensa contribuição para o progresso europeu. Para Voltaire, Luís XI de França (14231483) - o "primeiro rei absoluto da Europa" - golpeou a "anarquia" senhorial e abriu caminho para a pacificação do Reino, removendo o principal obstáculo imposto ao 
progresso pela barbárie da Idade Média (VOLTAIRE, 1963, v. 2, p. 1-11). O monarca ajudou a França a superar uma "forma de governo" - a "feudal" - em que os senhores nobres exerciam um poder tirânico sobre os subalternos, em especial sobre os camponeses. No mundo "feudal", o exercício da justiça era contraditório e incapaz de delimitar com clareza as instâncias competentes de cada senhor ou magistrado, pois todos pretendiam legislar e julgar, criando conflitos sem fim (VOLTAIRE, 1963, v. 2, p. 17-21). Segundo o Ensaio sobre os costumes, antes do século XV, "os senhores de castelos e das terras, que compunham o corpo da nobreza em todo país (...) submeteram à servidão tanto quanto puderam os habitantes de suas terras" (VOLTAIRE, 1963, v. 2, p. 27). Só eram conhecidas as "leis que os mais poderosos fizeram para o serviço dos feudos". A França medieval parecia um "conjunto monstruoso de membros que não formavam um corpo". O fortalecimento do rei, a partir da Renascença, golpeou essa monstruosidade.

Montesquieu também detecta os problemas decorrentes da autonomia da nobreza medieval. No livro quinto do Espírito das leis, ele avalia que "a França [na Alta Idade Média] se achava dividida em uma infinidade de pequenos senhorios que reconheciam antes uma dependência feudal que uma dependência política, era muito difícil que uma única lei pudesse ser autorizada" (MONTESQUIEU, 1949, v. 2, p. 218). No período, o poder monárquico apresentava-se ineficaz e confuso, pois o rei não escolhia os juízes e os comandantes militares (MONTESQUIEU, 1949, v. II, p. 392-393), ou seja, "quase não tinham autoridade direta" sobre os súditos (MONTESQUIEU, 1949, v. 2, p. 397). Curioso é que ele não recorre à famosa tipologia - república (democrática ou aristocrática), monarquia e despotismo - para elucidar as características do "governo feudal". Prefere afirmar, por exemplo, que "o reino se encontrou sem domínio". O "governo feudal" é definido negativamente: faltam-Ihe "leis", "política", "domínio" etc. Talvez represente uma variação muito corrompida e imperfeita da monarquia.

Um pouco mais tarde, a História das duas Índias, na já referida terceira versão, retomou as críticas à nobreza feudal, composta de "pequenos soberanos que abusavam de sua autoridade e resistiam ao príncipe". Eles desprezavam os "trabalhos úteis" e prejudicavam o desenvolvimento do "comércio", pois estabeleciam "direitos" que encareciam e dificultavam a circulação de mercadorias. Quando Flandres e as cidades italianas e alemãs prosperaram graças à liberdade de "comércio", os príncipes, impressionados, começaram a se opor aos "barões", favoreceram as companhias de mercadores e diminuíram "pouco a pouco a anarquia e a tirania feudais". Assim, "quando as riquezas do povo puderam ser úteis aos reis contra os barões, as leis melhoraram a condição do povo" (RAYNAL, 1780, t. 1, p. 20-27).

Em face do monstruoso "governo feudal", a centralização monárquica, para os filósofos moderados do século XVIII, representou um grande progresso. Se a república Ihes parecia sedutora, a monarquia fora uma resposta histórica decisiva para os problemas produzidos pela "tirania" anárquica da nobreza feudal. O rei, cada vez mais poderoso, foi capaz de submeter os senhores, favorecer os "trabalhos úteis" e viabilizar uma ordem institucional estável. Apesar das diferenças analíticas, eis a conclusão de boa parte dos pensadores das Luzes: a partir da Renascença, a 
centralização monárquica manteve a desigualdade e consagrou hierarquias sociais injustas, mas eliminou a "anarquia" dos pequenos "tiranos" medievais, possibilitando o despontar de uma ordem pública regulada por leis. Se por um lado as monarquias modernas tinham limites e defeitos, por outro, foram úteis para o progresso da vida civil. Como é possível notar, o discurso político ilustrado abordou o assunto de um ponto de vista histórico. Quando tratarmos da obra de Ribeiro Sanches, será possível demonstrar como o mesmo modelo de interpretação histórica foi utilizado para pensar o caso português, reaparecendo a crítica ao "governo feudal".

Para os ilustrados franceses e portugueses, mesmo depois da Idade Média, a fragmentação política continuava a ameaçar os governos monárquicos. A decadência ibérica exemplifica a questão. Felipe IV de Espanha (1605-1665), soberano de Portugal até 1640 , foi descrito por Voltaire como um príncipe que perdeu o controle do Império português por negligência e quase ficou sem a Catalunha por "abuso de poder". Mas o principal problema não era a inépcia individual dos monarcas. No Império Habsburgo do século XVII, cada "província" era "um pequeno reino", pois "não se soube fazer de todas as partes do reino um todo regular". A fragmentação, para Voltaire, produziu "abusos onerosos" e dificultou o comércio interno, comprometendo as manufaturas. Apesar das riquezas da América, a monarquia era pobre e incapaz de atender as demandas militares. Assim, "o reino de Felipe IV foi apenas um encadeamento de perdas e desgraças” (VOLTAIRE, 1963, v. 2, p. 628-629). Os holandeses tomaram a maior parte das possessões orientais e Portugal, por fim, conseguiu a independência. A deficiente centralização monárquica foi decisiva para o fracasso do Império Habsburgo. Outros fatores também foram determinantes no processo: "a sã filosofia ali sempre foi ignorada"; "a Inquisição e a superstição perpetuaram os erros escolásticos"; "as artes mecânicas eram todas muito grosseiras"; "o orgulho, a devoção, o amor e a ociosidade compunham o caráter da nação” (VOLTAIRE, 1963, v. 2, p. 632-633). Enfim, a combinação de fatores institucionais, econômicos e culturais determinaram a ruína.

A decadência monárquica, para os ilustrados, não derivava apenas do obscurantismo das elites, provinha também da própria estrutura política e social dos Estados, da deficiente articulação de sua ordem complexa. Para evitar a decadência, além de esclarecer os grupos dirigentes, seria necessário criar mecanismos institucionais que garantissem a unidade política e o desenvolvimento da economia. O progresso exigia um amplo conjunto de providências governamentais que articulassem vários fatores.

Certamente seria possível encontrar no século XVIII posições distintas das que apresentei aqui. Rousseau, em alguma medida, submeteu a monarquia a uma crítica mais severa e mais distante da "história filosófica". Todavia, neste artigo, analiso autores que, apesar de simpatias pela república, admitiram os benefícios históricos dos regimes monárquicos e, em vista disto, os defino como moderados. A princípio, penso que eles estiveram mais próximos do discurso político das Luzes ibéricas. Pretendo sustentar essa afirmação com a análise das obras de Ribeiros Sanches.

Como tentarei demonstrar a seguir, a parte mais esclarecida da elite portuguesa, mesmo se organizando a partir de práticas e referências aristocráticas e corporativas, participou da elaboração da crítica ao regime monárquico. Ela se apropriou, sem dúvida, 
dos filósofos moderados, mas também formulou avaliações sobre sua monarquia que, por caminhos complexos e mal conhecidos, foram incorporadas pela "história filosófica" dos franceses.

\section{Luzes e "república das letras" em Portugal}

Desde o fim do século XVII, membros das "redes governativas" existentes no Império português apontavam suas debilidades e refletiam sobre as mudanças necessárias. Segundo Maria de Fátima Gouvêa, essas "redes" articulavam diversos pontos do Império e, nelas, fidalgos, letrados e grandes mercadores compartilhavam interesses econômicos, indicações para cargos, responsabilidades administrativas e relações de parentesco. Em boa medida, essa elite imperial tentava reforçar as "centralidades régias". Seus participantes dependiam do domínio imperial e propunham reformas, como o fez em 1700 o secretário de governo em Goa, Guerreiro Coelho, ao enfatizar a necessidade de aperfeiçoar o controle da Fazenda Real e o recrutamento de oficiais régios (GOUVÊA in FRAGOSO; GOUVÊA, 2010, p. 176-179). A proposta de Coelho deixa transparecer certa inquietação com as debilidades administrativas do Império. Seja como for, a "centralidade da coroa", segundo a historiadora, residia no poder de confirmar a posição hierárquica dos indivíduos, povis a coroa definia os regimentos que serviam de suporte para "toda essa complexa engrenagem governativa" e conferia vigência à "lógica de prestígio", pois reconhecia os "serviços" que deveriam ser recompensados (GOUVÊA in FRAGOSO; GOUVÊA, 2010, p. 181). Depois da Guerra da Restauração (1640-1660), os monarcas portugueses relacionaram sua política de mercês com a "apresentação de serviços ultramarinos" e submeteram as principais linhagens aristocráticas a um processo de disciplinação na corte (GOUVÊA in FRAGOSO; GOUVÊA, 2010, p. 184). As "redes governativas" do século XVIII se configuram a partir desse processo. O bom funcionamento do Império precisava delas, porém, elas estavam obrigadas a servir o rei, pois reconheciam sua autoridade. A llustração portuguesa floresceu no seio dessas “redes", portanto, é necessário considerar o seu papel no desenvolvimento da primeira.

Para tal, convém ter em mente que, na monarquia portuguesa, diferente da monarquia francesa analisada por Montesquieu, era diminuta a importância dos "corpos políticos intermediários" e o Reino apresentava uma "invulgar homogeneidade institucional” (MONTEIRO, 2007, p. 28-29). Depois da Restauração de 1640, "os poderes senhoriais nunca se configuraram como polos de resistência e de produção de identidade", pois seus territórios eram pequenos, suas atribuições limitadas e a fidalguia passou a se concentrar na corte, atrofiando suas clientelas locais, ainda que, com as "redes governativas", pudesse coordenar grupos de dependentes em toda extensão do Império. Por outro lado, a nobreza "não constituía um grupo corporativo com uma identidade forte". A Igreja era um caso mais complexo, mas os conflitos internos e a tradição regalista limitavam sua resistência ao monarca. Não existia em Portugal "instituições provinciais" de raízes senhoriais e as instâncias intermediárias entre o poder central e o poder local (corregedores, provedores etc.) eram nomeadas pelo monarca. O único contraponto significativo ao poder central eram as câmaras 
municipais. Quanto às Cortes, sua vitalidade foi diminuindo na segunda metade do XVII e não foram convocadas durante todo século XVIII. Todos os grandes tribunais se localizavam em Lisboa e seus membros estavam enredados na sociedade de corte. No século XVIII, dificilmente se pode descrever "a monarquia portuguesa como uma constelação de poderes", pois é notória a "escassa expressão política" de qualquer tipo de "corpo intermediário" (MONTEIRO, 2007, p. 31-36). A maior parte das rendas da grande fidalguia eram "doadas pela coroa" e não provinham de seus bens hereditários. Para ela, "o exercício dos poderes senhoriais" tinha "limitada importância” (MONTEIRO, 2007, p. 91). Por isto, buscou "monopolizar as presidências dos tribunais, os comandos dos exércitos, os mais destacados governos coloniais, os bispados mais importantes" (MONTEIRO, 2007, p. 137). No que, aliás, parece bem-sucedida, em face do efetivo predomínio de seus membros nos postos de comando das principais áreas do Império (CUNHA; MONTEIRO in CARDIM; CUNHA; MONTEIRO, 2005, p. 211-242). Note-se que as "redes governativas" identificadas por Gouvêa eram capitaneadas por me mbros dessa fidalguia que, em posse dos principais cargos imperiais, recrutavam clientes subalternos (letrados, soldados etc.) para auxiliá-la, concedendo-lhes parcelas dos benefícios que monopolizavam. Assim, as "redes governativas" eram muito dependentes do poder monárquico e este, na ausência de um amplo aparelho burocrático-administrativo profissional, só se efetivava por meio delas. A reflexão política no interior das "redes" se processou tendo como fundamento essa dupla dependência.

Talvez a crítica ilustrada aos poderes senhoriais de origem feudal fosse digerível para parte dessa nobreza mais dependente do Império do que de seus senhorios. Não é absurdo pensar que os setores mais esclarecidos da fidalguia portuguesa estivessem mais preocupados com a eficiência do aparelho administrativo da monarquia do que com a preservação de seus privilégios provincianos. Ou, de modo um pouco paradoxal, as duas coisas poderiam interessá-los igualmente. Sendo assim, não deve surpreender que os primeiros sinais de assimilação do pensamento ilustrado possam ser observados em clientelas de iminentes fidalgos como os $3^{\circ}$ e $4^{\circ}$ condes de Ericeira, Luiz de Menezes (1632-1690) e Francisco Xavier de Menezes (1674-1743), este último, diretor da Academia Real de História de Lisboa e admirador de Newton e Voltaire (MAXWELL, 1997, p. 13). A preocupação como o desempenho administrativo da monarquia e a atenção ao pensamento político ilustrado se acentuaram na segunda do século XVIII, durante o governo pombalino, justamente o período em que Sanches produziu a maior parte de seus textos. Então, segundo José Subtil (2011), observase a substituição de um sistema político fundado na administração passiva e na gestão de mercês por outro mais ativo e reformista. Neste último, os administradores estatais, de forma crescente, procuraram interferir em diversos setores da vida social, como a educação, a saúde pública, a economia etc., e agir de modo a incidir sobre entidades abstratas como o "território" ou a "população". O governo da "graça" e da "Justiça" dava lugar, paulatinamente, ao governo das finanças, das obras públicas, dos aparelhos estatais. Para tal, concentrou-se a decisão administrativa nas secretarias de Estado e nas intendências. Ora, nada disso se realizou sem apoio das lideranças das "redes governativas", o que indica a inclinação de parte da elite portuguesa para 
uma transformação no modelo de governo. A partir de então, "operou-se a conversão do centro de poder dos tribunais e conselhos para as secretarias de Estado que passaram a apreciar os problemas pelo ângulo racional e não jurisdicional" (SUBTIL in CARDIM; CUNHA; MONTEIRO, 2005, p. 266-267). Nas colônias, ocorreu uma "reforma completa da estrutura administrativa", com a criação de companhias de comércio, de novos mecanismos de controle dos indígenas e o redesenho dos limites territoriais, tudo no sentido estabelecer um "controle racional sobre a economia e a revitalização do Estado” (MAXWELL, 1997, p. 19). Como veremos, a obra de Sanches respondia ao anseio reformista.

No mesmo período da publicação das obras de Montesquieu e Voltaire, Sanches e outros autores portugueses pensavam as reformas institucionais a partir da avaliação da história da monarquia lusitana. Na época, formava-se em Portugal "uma república das letras de viés iluminista" que "se imiscuía no Estado, colocava sua capacidade a seu serviço, usufruía de privilégios e, ao mesmo tempo, promovia sua própria ascensão social" (FURTADO in FRAGOSO; GOUVÊA, 2014, p. 62). Fariam parte dessa "república" homens como Luís da Cunha, Pina e Proença, o citado $4^{\circ}$ Conde de Ericeira, o Conde de Tarouca, o Infante D. Manuel, Silva Teles, Cardeal da Mota e Alexandre de Gusmão (FURTADO in FRAGOSO; GOUVÊA, 2014, p. 66-72). Mesmo Pombal parece ligado a esse grupo. Quando representante diplomático em Viena, entre 1745 e 1750, manteve contatos frequentes com personagens importantes da llustração austríaca como o holandês Van Swieten, um dos inspiradores das propostas ilustradas da imperatriz Maria Tereza e correspondente de Ribeiro Sanches. Pombal fazia parte de "uma geração de funcionários públicos e diplomatas portugueses que haviam meditado muito sobre a organização imperial e as técnicas mercantilistas que acreditavam houvessem ocasionado o poder e a riqueza surpreendentes e crescentes da França e da Grã-Bretanha" (MAXWELL, 1997, p. 9-10).

O influente diplomata Luiz da Cunha (1662-1749) foi uma referência para essa geração (FURTADO in FRAGOSO; GOUVÊA, 2014, p. 83-87). Cunha pensava que "os interesses portugueses passavam pelo desenvolvimento manufatureiro do país" e questionava a excessiva influência britânica (SILVA, 2006, p. 40-41). Preocupava-se, sobretudo, com a "criação do instrumental humano capaz de executar as reformas". Em texto dirigido a seu sobrinho, escrito na década de 1740, Cunha recomendou que os principais servidores da coroa deveriam ter bom nascimento, "instrução" e "experiência", articulando os novos referencias das Luzes, como o conhecimento científico, com os qualificativos tradicionais de "probidade e prudência" (SILVA, 2006, p. 54-58). Antes da publicação do Ensaio sobre os costumes e da História das duas Índias, Cunha, na primeira metade do século XVIII, já indicava a fragilidade do Império português, o poder prejudicial da Igreja, a necessidade de desenvolvimento manufatureiro e o perigo da supremacia inglesa. Boa parte de seu diagnóstico reaparece nas obras dos filósofos franceses.

Certamente Cunha integrava o circuito europeu de troca de ideias, o ambiente global no qual as Luzes nasceram e se desenvolveram desde o século XVII. Como alertou Jonathan Israel (2209, p. 41-50), é necessário pensar as Luzes com "um fenômeno 
em essência europeu" que se disseminou em cada um dos países sem perder seu núcleo comum de ideias e perspectivas analíticas. Além de ser membro das "redes governativas" do Império português, afinal chegou a altos postos diplomáticos, Cunha foi representante da corte lisboeta em Londres, Madri, Paris e Haia (SILVA, 2006, p. 37). Ele "inseria os problemas de Portugal no contexto de sua relação com a Espanha, sua dependência e exploração econômica pela Inglaterra e no que ele acreditava ser a fraqueza autoimposta de Portugal no tocante à falta de população e espírito de iniciativa" (MAXWELL, 1997, p. 16). Assim, Cunha sabia da necessidade de pensar os problemas portugueses a partir do quadro internacional do século XVIII. Para tal, não bastava o conhecimento tradicional de doutrinas jurídicas, morais e teológicas ministrado em Universidades como a de Coimbra na primeira metade do século. No tumultuado mundo dos grandes impérios da época, exigia-se da elite governante o domínio de um saber enciclopédico. Por mais que estivesse presa ao sistema de mercês ou à ortodoxia católica, ela não podia ignorar esse desafio.

É possível pensar que a "república das letras" lusitana se confunde com algumas das "redes governativas" ou se estruture no seu interior. Conhecendo bem o funcionamento do Império, ela pode ter oferecido material para as obras dos filósofos e, por outro lado, também se apropriou delas em função de seus interesses e problemas. Não ocorria apenas uma importação parcial e precária das Luzes promovida por "estrangeirados" residentes no exterior (como Cunha e Sanches).

"Estrangeirado", aliás, não me parece um termo adequado para definir os ilustrados portugueses com larga experiência europeia. O termo está relacionado ao suposto isolamento português a partir do fim da Renascença. Segundo historiadores importantes do século XX, como Antônio Sérgio, o Império lusitano seria um "sistema fechado", refratário às transformações econômicas e intelectuais observáveis em outros lugares da Europa. Nos séculos XVII e XVIII, alguns poucos portugueses residentes no exterior e quase desconectados da vida nacional, os "estrangeirados", teriam propagado novas ideias e estabelecido algum contato de Portugal com a Revolução Científica e as Luzes. Jaime Cortesão, por exemplo, apresentou Ribeiro Sanches como um autor de formação estrangeira que não compreendeu seu país de origem (cf. MIRANDA, 1990/1991, p. 35-39)

Nas últimas décadas, questionou-se essa caracterização. Como assinalou Ana Cristina Araújo (2003, p. 21), a definição de "estrangeirado", assimilando "à letra" a "concepção de progressos das Luzes", sugere a existência de uma "vanguarda intelectual alienígena, condenada a ser, em termos históricos, porta-voz do futuro", o que representa, para autora, uma distorção interpretativa. Tiago Miranda (1990/1991, p. 69), ao apreciar a complexidade do papel dos ditos "estrangeirados" na cultura portuguesa do século XVIII (o termo firmou-se após as Guerras Napoleônicas), conclui que não parece admissível apresentá-los como um "grupo definido e orgânico", capaz de monopolizar as críticas à monarquia portuguesa "em benefício de um projeto vindo de fora”. Letrados portugueses e espanhóis conheciam as novidades científicas e filosóficas da Europa além-Pirineus e, de maneira eclética e cautelosa, se apropriaram de muitas delas. Eles não experimentaram um isolamento asfixiante, pontualmente 
colocado em questão por personagens que viviam no exterior, distantes da realidade nacional. Esses personagens, na verdade, mantinham fortes ligações com Portugal e este continuava a ocupar um "lugar primordial" em seus projetos e "sentimentos corriqueiros” (MIRANDA, 1990/1991, p. 49). No mínimo, pode-se afirmar que formavam uma "rede" de portugueses com larga experiência no exterior cujo objetivo não era somente transmitir conhecimentos estrangeiros, mas criar "mecanismos nacionais de larga escala capazes de propiciar, a longo prazo, uma produção científica independente" (CARNEIRO; DIOGO; SIMÕES, 2000, p. 593-594). Diversas políticas pombalinas e pós-pombalinas - as reformas da universidade e do sistema educacional, a criação da Academia de Ciências, as mudanças na legislação etc. - evidenciam a importância dessa perspectiva de ação para os rumos dos negócios públicos. Era profunda a conexão entre os membros da "república das letras" e as instituições governamentais do Império, como evidencia a trajetória de Luís da Cunha (FURTADO in FRAGOSO; GOUVÊA, 2014, p. 87-102). Não há porque pensar em "estrangeirados" escrevendo alheios aos problemas e às demandas do governo de seu país de origem.

Todavia, alguns estudiosos contemporâneos insistem que a "difusão da cultura e da sociabilidade das Luzes parece limitada" em Portugal, pois a llustração portuguesa não ganhou autonomia frente aos círculos oficiais e não formou uma "opinião pública" significativa (MONTEIRO in FRAGOSO; GOUVÊA; 2014, p. 140-141). A observação é discutível, pois não há como negar que as políticas da monarquia, a partir de primeira metade do século XVIII, cada vez mais dialogavam com as Luzes. De maneira crescente, os ilustrados estavam pautando os governos em toda Europa, inclusive em Portugal. De resto, a monarquia precisava dessas conexões ilustradas para enfrentar os desafios internacionais. As "redes" que governavam Portugal não foram indiferentes à llustração e, ao contrário, representaram uma espécie de estufa onde ela pode subsistir.

A criação de Academias ao longo do século XVIII evidencia essa conexão. De maneira tímida, começava a emergir uma "opinião pública”: surgiram jornais que denunciavam "a ignorância e os erros do passado" em favor da "realização futura da razão", apresentando o século XVIII como "memorável na história do juízo humano" (ARAÚJO, 2003, p. 66-85). Assim, "dotada de mecanismos de imposição próprios, a opinião pública conquista, gradualmente, um lugar de destaque na vida cultural e política do país" (ARAÚJO in CRUZ et alii, 2004, v. 1, p. 200). As Luzes penetraram no mundo luso-braseiro e repercutiram nas teias de letrados, por vezes libertinos com ligações maçônicas e potencialmente sediciosos em termos religiosos e políticos. Eles conviviam na Universidade de Coimbra, em academias, nos círculos literários e não apenas na malha administrativa do Império (FURTADO in RODRIGRES, 2012, p. 291-321).

O médico Antônio Nunes Ribeiro Sanches (1699-1783) estava inserido nesse tecido de sociabilidades. Conheceu Luís da Cunha em Leiden, Holanda, no início dos anos 1730 e, na década de 1740, voltou a conviver com o diplomata quando se transferiu para Paris, onde ambos residiam. Sanches acompanhou, como médico, os últimos anos da vida de Cunha (cf. FURTADO in FRAGOSO; GOUVÊA, 2010, p. 99-100; LEMOS, 1911, p. 101-102 e p. 167-168). Na juventude, ainda em Portugal, travou relações com Pina e Proença (SÁ in SANCHES, s/d, p. 27). Sua correspondência revela um contato 
permanente com literatos e autoridades portuguesas, em especial diplomatas, escrevendo vários textos a pedido destas últimas (LEMOS, 1911, p. 167-189; RAMOS JR., 2013, p. 65-74). Importante lembrar que muitos diplomatas portugueses, no século XVIII, chegaram às secretarias de Estado e participaram ativamente da emergência do "governo moderno", em especial pelo seu conhecimento da "grande política internacional” (CARDIM; FELISMINO; MONTEIRO in CARDIM; CUNHA; MONTEIRO, 2005, p. 332-333). O trabalho de Sanches, portanto, deve ser compreendido tendo em vista as inquietações e perspectivas dessa "república das letras" formada pelos membros mais instruídos das "redes governativas" da monarquia portuguesa.

\section{Ribeiro Sanches e a "monarquia gótica"}

A obra de Sanches é vasta e diversificada, escrita em português e francês. Viveu e atuou como médico em vários países da Europa (Portugal, Espanha, Inglaterra, Holanda, Rússia e França). Formado em medicina pela Universidade de Salamanca, Espanha, ele saiu de Portugal com menos de trinta anos e sua decisão pôde ter sido motivada pelo temor do Santo Ofício, já que pertencia a uma família de cristãos-novos cujos membros enfrentaram vários processos inquisitoriais (LEMOS, 1991, p. 53-70).

Sanches teve experiência direta com diferentes regimes políticos: além das monarquias portuguesa e francesa, conheceu de perto a monarquia parlamentar inglesa, a república holandesa e o czarismo russo (LEMOS, 1911, p. 85-136; RAMOS JR, 2013, p. 53-65). As estadias na Holanda e na Rússia (onde também integrou a Academia de Ciências), durante as décadas de 1730 e 1740, e mais tarde em Paris (a partir de 1747), possibilitaram sua participação em "redes" de ilustrados atuantes em toda a Europa. Segundo George Dulac (2002, p. 262-270), dialogou com filósofos franceses (certamente com Buffon, Delisle, Diderot, Raynal e Holbach), autoridades russas, letrados e diplomatas portugueses (em especial no contexto das reformas pombalinas). Eram "redes" distintas, mas Sanches, em várias ocasiões, operou como um elo de ligação entre elas: oferecendo notícias sobre publicações e novidades francesas para russos e portugueses (correspondia-se com regularidade com a Academia de Ciências russa e com membros da Academia de História de Lisboa); informando os franceses sobre as condições sociais e os fenômenos naturais dos dois impérios. Alguns dos manuscritos que analisaremos a seguir, foram redigidos para atender demandas desses interlocutores (em especial dos russos e dos portugueses) e sugerir ações governamentais. Um exemplo: Kenneth Maxwell (1997, p. 26) afirma que o Tratado de conservação da saúde dos povos (1756) serviu como manual para a restauração de Lisboa liderada por Pombal após o terremoto de 1755. Todavia, é difícil saber com precisão como os textos circularam e foram lidos, ainda que vários deles não fossem apenas anotações pessoais guardadas na gaveta de seu escritório.

Assim, além das "redes governativas" portuguesas, ele contatou "uma comunidade internacional de eruditos unida por preocupações comuns e trocas voltadas aos interesses da ciência" (DULAC, 2008, p. 193), "redes" de ilustrados com diversas orientações políticas e religiosas. No caso dos portugueses, vários participantes dessas "redes" eram médicos (CARNERIO; DIOGO; SIMÕES, 2000, p. 596), como ele, 
e a atuação profissional contribuiu para sua inserção nesses círculos. Sua produção, porém, transcendeu os temas relativos à saúde. É notório seu esforço constante para comparar diferentes sociedades e cenários naturais (DULAC, 2002, p. 271272). Sanches conhecia muitos países europeus, manteve contato com homens de vários lugares (de jesuítas estabelecidos na China a médicos brasileiros), tinha, portanto, a experiência e os dados necessários para contrastar instituições e hábitos de distintas partes do mundo. Como outros membros da "república das letras" da llustração europeia, detinha um conhecimento enciclopédico. Para avaliar sua obra, é necessário ter isso em mente.

Como dito, Sanches escreveu sobre muitos assuntos. Neste artigo, me interesso por sua análise da monarquia portuguesa. Ao diagnosticar e conceituar seus problemas, Sanches dialogou com a crítica da "história filosófica" ao regime monárquico e, ao mesmo tempo, procurou orientar a elite que governava Portugal.

Já se afirmou que ele localizou "sobretudo no domínio cultural e na ambiência intelectual de nossas escolas (...) os maiores entraves à modernização das estruturas políticas, sociais e econômicas do país" (ARAúJO, 1984, p. 381). Sem dúvida, Sanches, afinado com a estratégia pombalina de criar em Portugal uma "comunidade profissional de homens de ciência", apontou as debilidades culturais dos portugueses e trabalhou, como outros colaboradores de Pombal, no sentido de secularizar o sistema escolar (CARNEIRO, DIOGO, SIMÔES, 2000, p. 600-603). Todavia, a estrutura institucional e as hierarquias tradicionais da monarquia também foram objeto de análise. Como nas obras de outros ilustrados, os problemas culturais eram interpretados como parte de um todo de conexões complexas, de um processo histórico mais amplo. Como observou Silva (2006, p. 58-60), Sanches objetivou a derrogação "das leis góticas" de Portugal, que se caracterizavam pelos "privilégios da nobreza e imunidades dos eclesiásticos". A passagem da "monarquia gótica" para o "Estado civil” foi o cerne da proposta política de Sanches.

Para aprofundar a análise da dicotomia "monarquia gótica”/“Estado civil”, insisto na proximidade entre Sanches e os filósofos moderados franceses, em especial no que se refere à história dos regimes monárquicos. A obra em que o termo "monarquia gótica" apareceu, as Cartas sobre a educação da mocidade, foi escrita no mesmo período das obras de Voltaire e Montesquieu e antes dos livros de Raynal. Sua primeira publicação ocorreu em 1760 e teve apenas 50 exemplares. Foram todos entregues ao representante da coroa portuguesa em Paris, Monsenhor Salema, sendo enviados ao Marquês de Pombal (LEMOS in SANCHES, 1922, p. V-X). O livro não foi mais impresso no século XVIII e teve, portanto, circulação restrita, mas era uma espécie de encomenda do governo de Lisboa e provavelmente foi lido na corte.

O texto, que apresenta diversas propostas para a educação portuguesa, também realiza uma crítica extensa e profunda à estrutura social e política do Reino. A Igreja, em especial, recebe uma avaliação bastante dura, mais um ponto de contato entre Sanches e filósofos como Voltaire e Raynal. Ao investigar as razões que levaram a Igreja a controlar o sistema educacional em quase toda Europa até a Reforma Religiosa do século XVI, Sanches (1922, p. 12-16) aponta como bispos e prelados, desde o início 
da Idade Média, receberam de monarcas enfraquecidos a "jurisdição temporal sobre os leigos", fazendo com que "o Estado civil fosse regido e governado pelas regras e constituições dos conventos e dos cabidos”. Assim, os princípios organizacionais da Igreja passaram a orientar as instituições civis e, pior, os clérigos assumiram, ao longo do período medieval, as funções das autoridades públicas. Não vou reproduzir aqui todas as decorrências desse processo, saliento apenas que, para Sanches, ele comprometeu a eficiência dos Estados modernos. O autor admite que o soberano não pode exercer todas as funções de governo e precisa conceder incumbências aos súditos "mais capazes de as exercitar e cumprir", conferindo-lhes uma "porção do poder da majestade" (SANCHES, 1922, p. 22). Mas o clero deveria ter apenas "jurisdição sobre as consciências", não sobre as "ações exteriores humanas" (SANCHES, 1922, p. 27). Conseguiu poderes abusivos em um período bárbaro (a Idade Média), quando os reis eram fracos e a nobreza guerreira, muito ignorante, estava impossibilitada de ocupar os cargos que exigissem o domínio das letras, como as atribuições jurídicas ou educacionais. Trata-se de um perigoso desvio de funções, pois o "corpo" eclesiástico acabou por impor aos Estados modernos seus princípios e procedimentos, em especial nas questões educacionais, mas não exclusivamente nelas. Os clérigos conseguiram "sufocar e absorver quase toda jurisdição política e civil", tendo como pressuposto que deviam julgar "tudo aquilo que é pecado" (SANCHES, 1922, p. 42-43). Em nome da defesa da fé, puderam punir com castigos violentos, confiscar bens e proclamar censuras públicas, ou seja, transformaram a "intolerância cristã" em "intolerância civil" ao impor seus preceitos religiosos para todos os súditos. O que se exigia dos membros de um convento medieval - a adesão incondicional às regras clericais - foi solicitado de todos os membros do Estado. As leis eclesiásticas se tornaram leis civis. Ao submeter o poder clerical à crítica, Sanches denunciou a interferência da Igreja nos negócios públicos, uma derrapagem medieval não corrigida que deturpou a ordem civil das monarquias, pois comprometeu a autoridade dos soberanos.

No que se refere à questão eclesiástica, a Rússia havia encontrado saídas institucionais melhores que Portugal. Sanches analisa o tema em um manuscrito de 1769, Meios que Pedro primeiro, imperador da Rússia, tomou para regrar os eclesiásticos do seu império. Para o autor, Pedro, o Grande, submeteu a Igreja Ortodoxa. Antes dele, o "estado eclesiástico" era "imperioso e rebelde". Pedro, quando assumiu o trono, "se declarou o primeiro bispo" e passou a controlar um sínodo que determina "todas as matérias eclesiásticas, cujas decisões não são válidas sem a firma do soberano" (SANCHES, s/d, p. 93-94). Graças a essas iniciativas, na Igreja russa "não se conhece intolerância, simonia, poder arbitrário, nem ambição que ofenda a sociedade civil”, pois "não tendo jurisdição alguma mais que a espiritual", ela jamais impõe aos súditos algum tipo de "vexação". Em contraste, os "reis católicos" nada ou pouco fizeram para que seu clero abandonasse o "espírito da sedição, contumácia e rebeldia" (SANCHES, s/d, p. 97). Pedro da Rússia aparece no manuscrito do médico português como uma espécie de referência para se pensar o tipo de relação desejável entre Estado e Igreja. Ele claramente concebeu a eliminação da jurisdição civil da Igreja como um grande benefício para a monarquia. Fica subentendido que o poder do clero em Portugal era um fator de desestabilização política, uma verdadeira ameaça 
à soberania dos reis. A centralização monárquica, na perspectiva do autor, deveria atingir inclusive a estrutura clerical e os assuntos religiosos. Se um autor tão bem articulado com as "redes governativas" portuguesas pensava algo do gênero, não é absurdo acreditar que concepções como as expostas acima encontrassem eco no seio da elite pombalina. Convém lembrar que Pombal, sem nunca questionar o caráter católico da monarquia, teve um conflito aberto com o papado e rompeu com o Vaticano entre 1760 e 1769, agindo "de modo a criar um Estado secular fortalecido por uma rejeição sistemática das reivindicações papais de jurisdição” (MAXWELL, 1997, p. 99). Por outro lado, nota-se que Sanches também estava bastante afinado com as críticas que os filósofos franceses faziam ao poder temporal da Igreja (cf. CASTRO in CRUZ et alii, 2004, v. 2, p. 399-406).

Não era apenas a Igreja que tinha "jurisdições" contestáveis de origem medieval. Na análise histórica de Sanches, como em Voltaire e Montesquieu, a nobreza guerreira também usurpou a autoridade dos príncipes. Nos reinos medievais, a "política (...) se reduzia a premiar o mais valente e o mais ousado com os primeiros cargos do exército, com propriedades de terras e com as primeiras honras daquelas monarquias", pois estas eram governadas como os grupos de conquistadores bárbaros. Nos séculos posteriores ao fim do Império Romano, os "conselhos gerais" dos reis repartiram as terras e as "jurisdições" - os "feudos" - entre os bispos e os principais chefes guerreiros, "de tal modo que ficava despido o monarca de toda jurisdição que deveria ter naqueles súditos". Sobre os senhores dos "feudos" não recaiam impostos, apenas o serviço de guerra. Naquele "império simplesmente militar", quase ninguém sabia ler e escrever, portanto, desprezava-se as ciências. A educação da nobreza, por exemplo, restringia-se à preparação para o combate corpo-a-corpo (SANCHES, 1922, p. 30-32). Os clérigos, como exposto acima, assumiram todas as tarefas intelectuais, enquanto os senhores guerreiros mantiveram privilégios e o poder de gerir a justiça nos seus "feudos". Em Portugal, os poderes senhoriais dos fidalgos foram consagrados pelos reis renascentistas como um prêmio por sua participação nas "conquistas" ultramarinas. Os senhores, ao longo do tempo, acostumaram-se, nas terras que receberam da coroa, a tratar os vilões como "escravos", destruindo o "vínculo da sociedade" pelos excessos cometidos contra os subordinados. Por outro lado, o fidalgo português, como não pode ser preso, "perde toda ideia de justiça, da ordem, da economia", conseguindo empréstimos forçados sem pagá-los. Seus privilégios comprometem a "jus da majestade" e a autoridade dos magistrados, a quem resistem e insultam (SANCHES, 1922, p. 81-83). Enfim, a concessão de senhorios comprometeu seriamente o desenvolvimento da monarquia em vários aspectos.

Voltaire e Raynal também definiram como "tirânico" o domínio dos senhores feudais sobre os camponeses. O Ensaio sobre os costumes apresenta o "governo feudal" dos reinos da Idade Média como uma ordem política incapaz de formar "corpos" coesos, pois permitia a autonomia dos "pequenos tiranos", ou seja, dos chefes de exércitos de cavaleiros. Naquelas circunstâncias, a única lei era a "que os mais poderosos faziam para o serviço dos feudos", ou seja, "a violência estava no lugar das leis” (VOLTAIRE, 1963, v. I, p. 443-451). Para Raynal (1780, v. II, p. 272-284), a França medieval se caracterizava pela "anarquia" promovida pelos "tiranos subalternos" (os 
senhores feudais) que, impondo "cadeias de escravidão" aos plebeus, impediam o desenvolvimento do "comércio". Portanto, era comum entre os ilustrados caracterizar o poder "feudal" como tirânico. Sanches, ao tratar da história da monarquia portuguesa, insistiu muito na mesma caracterização.

No Tratado para a conservação dos povos, publicado pela primeira vez em Lisboa no ano 1756, ao comentar o surgimento de hospitais em Portugal, o autor enfatiza que, até o século XII, em toda Europa verificava-se apenas "duas condições": a de "senhor" e a de "escravo". Na época, não havia hospital público, pois "cada nobre era soberano da sua vila, ou aldeia, que lhe pertencia”, ficando responsável pela saúde de seus "escravos". Algo que se alterou quando "os reis pouco a pouco deram liberdade aos povos" e surgiram instituições públicas de tratamento dos doentes (SANCHES, 1757, p. 136-137). Nota-se que a "liberdade" é apresentada como produto das restrições que os monarcas impuseram aos senhores locais. O fortalecimento do poder régio significou, para o autor, a possibilidade de emancipação dos plebeus e de criação de instituições verdadeiramente públicas.

Para Sanches, Voltaire ou Raynal, seja em Portugal ou na França, o "governo feudal" comprometeu a soberania monárquica e, por muitos séculos, impossibilitou o controle do rei sobre áreas decisivas da vida social, como a saúde e a educação. A permanência de "privilégios" de origem feudal também foi nociva para os camponeses e para as cidades, pois os nobres os tiranizavam. Como afirma um manuscrito de autoria de Sanches, Apontamentos para promover toda sorte de trabalho em Portugal (1777), os "privilégios" do tempo da "escravidão" feudal, ainda no século XVIII, obrigavam os agricultores portugueses a utilizarem os lagares, as azenhas, os fornos e os moinhos dos nobres de sua região, pois os senhores monopolizavam esses equipamentos. Os camponeses também não podiam vender seu vinho ou azeite antes dos senhores, fossem eles clérigos ou laicos. Assim, as "leis feudais", que "por inércia” continuavam a existir, tolhiam a expansão da agricultura portuguesa e impediam o crescimento das receitas da monarquia (SANCHES, s/d, p. 143-144).

Segundo os textos do médico português, a permanência dessas "leis", além de atingir a soberania dos monarcas, debilitava seriamente toda vida social e dificultava a solução dos principais problemas portugueses. Concedendo direitos abusivos, elas impossibilitavam a "igualdade entre os súditos" e, sem esta, é impossível haver "justiça, propriedade de bens, respeito aos magistrados" (SANCHES, 1922, p. 81-2). Note-se o conjunto terminológico característico das Luzes que o autor mobiliza: as "leis góticas" ou "feudais" inviabilizam a "liberdade" e "igualdade" que fundamentam a "justiça" e viabilizam a prosperidade. Sabemos como a mesma articulação de termos foi utilizada pela Assembleia revolucionária de 1789 para destruir o regime senhorial francês (LEFEBVRE, 1989, p. 130-133 e 159-163). Em sintonia com as críticas mais audaciosas dos ilustrados europeus, levedadas pelo "fermento republicano", o programa social e político de Sanches atacava o senhorio tradicional e a fragmentação do poder político. Mas que tipo de propostas derivou dessa crítica? Teria ela um sentido revolucionário? Como veremos nas próximas páginas, a resposta para a última pergunta é não. 
A preservação da herança medieval faz do Estado português uma "mistura da constituição gótica e da constituição daquelas monarquias das quais a base consiste no trabalho e na indústria". Liquidar esta ambiguidade e enfatizar o segundo tipo de "constituição" parece ser o objetivo da crítica de Sanches ao senhorio, pois só "pela agricultura e pelo comércio" os portugueses podem conservar suas "conquistas" no ultramar. Portanto, para manter o Império e aprimorar seu funcionamento, é necessário "derrogar as leis góticas que temos, que se reduzem aos excessivos privilégios da nobreza e às irmandades religiosas, as quais contrariam sempre o bom governo civil". Trata-se, na verdade, de aperfeiçoar e fortalecer uma forma de domínio político já existente, a saber: o poder do rei e de seus servidores sobre o conjunto dos súditos. $O$ objetivo é recorrer ao poder da coroa para acabar como os resquícios das pequenas tiranias senhoriais que fragmentam a soberania. A crítica às "leis feudais" não busca eliminar todo e qualquer tipo de distinção social, mas identificar "as causas das desordens presentes para evitá-las ou suprimi-las no decurso do tempo" (SANCHES, 1922, p. 75-76). Ora, apesar da menção constante à "liberdade" e à "igualdade", que fazem lembrar as tradicionais referências republicanas, a análise histórica de Sanches em nenhum momento sugere o fim do regime monárquico, mas traça uma diferença "entre monarquia fundada e conservada pela espada e aquela fundada pelo trabalho e pela indústria" (SANCHES, 1922, p. 80). Vejamos os termos exatos dessa distinção:

\begin{abstract}
... naqueles Estados que têm por base a sua conservação no trabalho e na indústria, não há neles nenhuma sorte de súdito mais pernicioso a sua harmonia do que é um nobre, ou um fidalgo, com os privilégios que lhe permitem as nossas Ordenações. A nobreza é essencial, naquelas Monarquias Góticas como a nossa, enquanto dependia a sua conservação de conquistar e de subjugar os seus inimigos; mas logo que se acabou a conquista, logo que não houve o que conquistar, é necessário que o legislador mude as leis: o Estado que tem terras e largos domínios, e que deles há de tirar a sua conservação, necessita decretar leis para promover o trabalho e a indústria, e derrogar ou abrogar aquelas que se estabeleceram no tempo que adquiriam com a espada. ${ }^{3}$ (SANCHES, 1922, p. 86)
\end{abstract}

As "monarquias góticas", com seus privilégios nobilitários, tiveram sua origem diretamente ligada à "conquista', não apenas ao obscurantismo e à ignorância. No período de constituição dessas monarquias, quando a atividade militar era intensa e brutal, a nobreza guerreira era útil. Mas quando o Estado precisa organizar a "indústria" e o "trabalho", quando necessita governar as "conquistas" de maneira racional e eficaz, a ordem "gótica" é desastrosa, pois garante "privilégios" prejudiciais à eficiência econômica e administrativa. Então, a "liberdade" e a "igualdade", de inspiração republicana, devem ser cuidadosa e seletivamente introduzidas pelo rei nas instituições monárquicas. A partir da segunda metade do século XVI, com a expansão ultramarina, a invenção da imprensa e o uso de armas de fogo, a Europa começou a conhecer as "obrigações de humanidade" entre povos e indivíduos, o que minou os pressupostos guerreiros da "monarquia gótica" e fez despontar a "monarquia política e civil" fundada - insiste o autor - na "igualdade dos súditos (não de condições), na 
propriedade de bens, no trabalho e na indústria”. No novo contexto, Portugal, para não perder tudo que conquistou e se desenvolver, precisa promover "a agricultura e as artes" que, pelo "interesse", tornam os súditos "humanos" e "dóceis". A prosperidade de lavradores, oficiais e mercadores "não se conserva com privilégios de fidalgos, com imunidades e jurisdição civil dos eclesiásticos, com escravidão e com a intolerância civil” (SANCHES, 1922, p. 99-101). É indispensável acabar com a "tirania" dos antigos senhores. Para tal, o rei e seus principais servidores devem tratar os súditos com isonomia, estabelecendo procedimentos legais sob inteiro controle do poder central.

Ora, mais uma vez, é identificável certa sintonia dessa perspectiva analítica com parte das iniciativas de Pombal e seus colaboradores. Maxweel (1997, p. 79) indica a "renovação da aristocracia" portuguesa, associada à "reafirmação do Estado", durante o período pombalino, pois em 1777 "um terço da nobreza se compunha de sangue novo". Era uma decorrência da "tentativa autoconsciente de modelar a aristocracia portuguesa", atraindo os fidalgos para atividades mercantis, mas também abrindo o governo para a participação dos grandes mercadores, em especial nos órgãos que conduziam a política econômica (Juntas de Comércio, Companhias com privilégios, Erário Público etc.) (MAXWELL, 1997, p. 92-93). Na década de 1770, é possível observar "a nova oligarquia mercantil firme e poderosamente entrincheirada dentro do corpo político", um grupo pequeno de agentes econômicos "que ele (Pombal) abrigara e nutrira com a assistência direta e indireta do Estado durante duas décadas" (MAXWELL, 1997, p. 149-150). O ministro de José I contava com esse grupo para engrandecer o comércio e a "indústria" de Portugal e, assim, enfrentar os desafios das disputas internacionais da segunda metade do século XVIII. Não se pode ver aqui a realização do projeto de Sanches, mas talvez a ideia de uma monarquia fundada no trabalho e na "indústria", em alguma medida, tenha inspirado as políticas pombalinas que desembocaram na formação da "oligarquia mercantil".

Em sua análise histórica, Sanches também lamenta que boa parte das riquezas obtidas com a expansão portuguesa foram parar nos países estrangeiros (Inglaterra, França, Países Baixos etc.) em troca de produtos manufaturados. A outra parte, acabou nas mãos da nobreza soberba e ociosa, "gastando sempre mais que suas riquezas" e "sepultada pelos vícios de toda dissolução". O "povo" pouco proveito obteve com as possessões e o crescente comércio português (SANCHES, 1922, p. 101-108). Eis outro desequilíbrio problemático para o desenvolvimento do Império. Os reis do século XVIII deveriam eliminar os elementos "góticos" da monarquia e, ao mesmo tempo, capacitar a elite dirigente para gestar com destreza e equidade as "conquistas" do período anterior. Como as obras dos filósofos franceses, os textos de Sanches condenam a manutenção das desigualdades tradicionais dos regimes monárquicos.

A condenação das hierarquias existentes nas monarquias europeias pode ter decorrências revolucionárias, como se observa em 1789, mas não necessariamente. Vimos que ela se encontra em vários filósofos moderados do século XVIII, críticos dos resquícios medievais dos regimes monárquicos, mas que procuram evitar os "perigos inerentes à proliferação da convulsão intelectual" e salvaguardar "os elementos essenciais das velhas estruturas" (ISRAEL, 2009, p. 36-39). 
Para compreender melhor essa posição moderada, convém analisar a contraposição conceitual entre "interesses" legítimos e benéficos dos agentes econômicos (comerciantes e produtores) e as paixões corrosivas de uma elite ociosa e ignorante (eclesiásticos e fidalgos). Segundo Hirschmann (2000, p. 55-63), em pensadores como Montesquieu, Voltaire, Robertson, Hume etc., "a atitude predominante quanto ao amor do ganho era positiva”, relacionada à demolição do "ideal aristocrático" do herói guerreiro. Vários deles caracterizaram o "doce comércio" como a forma dos homens se ajudarem uns aos outros por meio da troca dos "confortos da vida", pois "o comércio dá polimento aos costumes bárbaros e abranda-os". Esta tese permitia uma interpretação positiva de Impérios fundamentados nas trocas mercantis. Hume, por exemplo, definiu a aquisição de bens como uma "paixão calma", "capaz de triunfar sobre uma variedade de paixões turbulentas”. Para Raynal (1781, v. V, p. 88-89), qualquer um que puder viver dos frutos de seu trabalho e do comércio pacífico desenvolve "doces inclinações que inspira o interesse racional do bem-estar". No século XVIII, o "interesse", em especial o de natureza econômica, começou a ser visto como uma espécie de "amor próprio razoável" que poderia funcionar como antídoto às paixões destrutivas da nobreza guerreira (HIRSCHMANN, 2000, p. 44-45). Vemos como Sanches compartilhava as formulações conceituais desses filósofos moderados, defensores do "doce comércio", e as utilizava para elaborar uma crítica aguda às instituições tradicionais da monarquia portuguesa.

Ora, no contexto português, no qual a maior parte dos fidalgos dependia mais dos benefícios da expansão ultramarina do que dos patrimônios senhoriais, que significado podemos destilar dessa crítica? A “oligarquia mercantil em formação e a parcela da fidalguia mais envolvida com o mundo ultramarino - os líderes das "redes governativas" - talvez não fossem refratários ao questionamento de "privilégios" de origem feudal que, segundo Sanches, prejudicavam a eficiência do Estado protetor do "doce comércio". Como vemos pelos estudos sobre Luís da Cunha, parte da elite portuguesa estava preocupada em constituir um corpo dirigente mais dinâmico e instruído, capaz de administrar e manter a sua principal fonte de recursos e status: o Império. Acredito que os textos de Sanches, apesar de polêmicos, atendiam esses anseios, do contrário, ele não teria sido financiado para escrevê-los (cf. LEMOS, 1911, p. 167-189).

Além de atender o "interesse" de produtores e comerciantes, uma monarquia que privilegiasse o trabalho e a "indústria" atingiria dois outros objetivos políticos: o crescimento populacional e a autonomia do Estado. No manuscrito Dificuldades que tem um reino velho para emendar-se (1777), ele propõe que os governantes proclamassem "leis" "fundadas na conservação e [no] amor dos súditos", tendo como alvo o aumento da população e a "defesa geral do Estado" (SANCHES, s/d, p. 78). No Prólogo do Tratado da conservação da saúde dos povos, Sanches voltou a insistir no tema: "a mais sólida base de um poderoso Estado consiste na multidão dos súditos e no seu aumento, e que desta origem resultam as suas forças, poder, grandeza e majestade". Outro manuscrito, Algumas causas da perda da agricultura de Portugal (1777), traça uma relação muito clara entre aumento da agricultura, da "indústria" e da população, lamentando que "a principal falta no Reino de Portugal, é que seu governo 
econômico tem mui pouco súditos com salários”, enquanto abundam os eclesiásticos. Então, projeta que as câmaras municipais "podiam ser empregadas no governo do estado econômico de todo o Reino", regrando o uso das áreas de plantio, dos pastos, dos bosques, ou seja, sugere que os vereadores controlem e orientem as atividades produtivas no sentido de racionalizá-las (SANCHES, s/d, p. 118-120).

No mesmo período, redige ainda os Apontamentos para promover toda a sorte de trabalho em Portugal (1777), na verdade uma carta destinada ao embaixador português em Paris, Vicente Coutinho. O texto esmiúça a necessária integração entre atividades econômicas para fazer um Estado florescer e sua população crescer. O desenvolvimento do trabalho e da "indústria" só ocorre quando os proprietários de terras dispõem de recursos para contratar mão-de-obra e comprar animais e instrumentos, sem o que, as terras não são cultivadas, o que diminui a população e aumenta o número de ociosos dispostos ao crime. Por outro lado, para que a agricultura prospere, vários ofícios são necessários (ferreiros, serralheiros, pedreiros, tecelões etc.) e os artesãos também precisam de dinheiro para comprar matérias-primas e instrumentos. Por outro lado, para comercializar seus produtos, os agricultores e artesãos necessitam de boas estradas terrestres e canais de navegação. Sem o crescimento econômico que tudo isso possibilita, o Estado não terá recursos para sustentar universidades, médicos e jurisconsultos (SANCHES, s/d, p. 126-127). O governo, portanto, deve oferecer as condições básicas para a expansão de todas essas atividades econômicas, seja construindo os equipamentos públicos imprescindíveis (estradas, canais etc.), seja ajudando a financiar os agentes produtivos. Estado não é concebido aqui apenas como uma instância responsável por regular as relações entre os agentes e reprimir os criminosos. Deve criar as condições financeiras e materiais para o progresso material a partir de um complexo conjunto de ações integradas. Mas como conseguir recursos para a realização desse verdadeiro plano de desenvolvimento?

El Rei tirará esse dinheiro das mãos daqueles que o têm, ou seja, fidalgo, eclesiástico ou cidadão; apesar da lei, apesar dos privilégios, apesar dos decretos do soberano, ninguém deve ser eximido, nem isento de contribuir a resgatar o Estado, submergido na necessidade, caminhando a sua ruina. (SANCHES, s/d, p. 129).

A proposta de taxar todos os grupos sociais para financiar os agentes econômicos demonstra a que ponto Sanches estava disposto a levar a crítica aos tradicionais "privilégios" da nobreza e do clero português. Para viabilizar essa expansão do fisco e o financiamento estatal das atividades econômicas, ele, curiosamente, projeta a colaboração das câmaras municipais, a instituição regional portuguesa mais autônoma e que melhor exprimia os anseios das elites locais distantes da corte (BICALHO in BICALHO; FRAGOSO; GOUVÊA, 2001, p. 189-221). Cada câmara, segundo o Sanches (s/d, p. 132-133), deve estabelecer um "tesoureiro vereador" com dinheiro disponível para emprestar para os lavradores, registrando as dívidas e prestando contas para o "inspetor de agricultura" de sua província, inspetor assalariado pelo rei e com "instruções impressas" de como operar. O "inspetor de agricultura" - um verdadeiro 
burocrata (cf. WEBER, 2009, v. II, p. 198-233) - faria o "tombo das terras laboráveis, dos senhores a quem pertenciam, a sua extensão, o seu rendimento", produzindo dados que orientassem a atuação dos oficiais das câmaras. A proposta é instaurar um aparelho público que dirija, com o auxílio do poder local, a agricultura em toda monarquia. Essa articulação entre câmaras e "inspetores" da coroa parece uma tentativa de mobilizar as elites municipais para um projeto que, sob controle de uma burocracia estatal, atinja de maneira capilar o território. Ao Estado cabe orientar a economia privada, oferecendo recursos e infraestrutura para seu desenvolvimento, mas também criando um corpo de funcionários especializados capaz de conduzir a intervenção estatal e interagir com as elites regionais.

Como já observaram outros comentadores (cf. ВOTO, 2017, p. 65-68), nas obras Sanches o questionamento das prerrogativas da nobreza e do clero articulava-se como a formação de súditos preparados para a reforma das estruturas institucionais obsoletas. Para sustentar a autonomia portuguesa em um contexto de potências cada vez mais agressivas e perigosas, era necessário reorganizar a elite e educá-la para cumprir tarefas administrativas complexas, tais como a reorientação global da vida econômica. O ataque de Sanches aos "privilégios" não objetivava o fim das hierarquias sociais. Ele não projetou o fim da fidalguia ou da elite camarária, mas pensava mobilizá-las em favor da renovação da monarquia. Ao lado dessas elites tradicionais, projetou também a existência de um corpo de funcionários estatais que atuassem como verdadeiros burocratas. Estes seriam um dos pilares da superação da "monarquia gótica" por um Estado que promovesse o "trabalho" e a "indústria".

\section{Considerações finais}

A concepção de monarquia presente na obra de Sanches vai muito além do "paradigma da ação política" "jurisdicionalista" que, segundo Hespanha, teria conduzido a monarquia portuguesa até meados do século XVIII. Para essa concepção tradicional de poder, a "função do rei" era "manter a jurisdições dos restantes corpos políticos no equilíbrio estabelecido pela constituição (natural) da sociedade". As principais funções do poder central e dos "magistrados" eram a "defesa da paz" e a "salvaguarda dos direitos particulares". Tratava-se de um esquema teórico que firmava a ideia da superioridade "da justiça sobre a oportunidade, da ratio sobre o arbitrium", definindo a "prudência" (iurisprudentia), fundamento da arte de governo, acima da "utilidade" (oposta à "honestidade") e da "razão de Estado" (oposta à "consciência da justiça") (HESPANHA, 1994, p. 278-286). Entendia-se por "justiça" atribuir a cada parte "aquilo que Ihe é próprio", ou seja, possibilitar a "manutenção da ordem social e política estabelecida" (HESPANHA, 1994, p. 300-301). Ora, Sanches pensou para o poder central um raio de ação diverso e muito mais amplo. A coroa, por meio de seus funcionários e súditos eminentes, deveria corrigir os defeitos da "ordem social", não para mudá-la completamente, mas para eliminar seus elementos arcaicos nocivos ao progresso - como os "privilégios" de origem "feudal" - e possibilitar novas formas de intervenção estatal. Quanto a este último aspecto, em vez de se concentrar na defesa da "justiça" tradicional, o aparelho estatal projetado por Sanches assumiria funções 
muito vastas, tais como: preservar a saúde dos súditos, aumentar a população, educar os jovens, financiar e orientar as atividades produtivas, estimular o comércio e a produção de bens etc. Portanto, sua perspectiva política representava uma superação do paradigma "jurisdicionalista".

Por outro lado, a obra de Sanches comporta muitas afinidades com a "história filosófica” das Luzes. Como Voltaire e Raynal, ele criticou com veemência as tradições políticas das monarquias europeias herdadas da Idade Média. As "jurisdições” da Igreja e da nobreza, para os ilustrados, comprometiam a soberania dos monarcas e a eficiência do Estado como um todo. A nobreza e os clero, em geral, não tinham a formação adequada para conduzir os negócios públicos e responder aos desafios do século XVIII. É importante notar que a crítica de Sanches não foi uma simples repetição dos argumentos da "história filosófica" francesa. As Cartas sobre a educação da mocidade, por exemplo, foram escritas e publicadas no mesmo período do Ensaio sobre os costumes (por volta de 1760). Suas reflexões históricas, apesar das semelhanças, atentaram para as especificidades do caso português e utilizaram, por vezes, formulações discursivas aparentemente originais, como o significado do adjetivo "gótico". No período, parece existir um amplo debate sobre as monarquias no qual a obra de Sanches estava inserida, mas como uma contribuição criativa.

As reflexões de Sanches também apresentam uma considerável proximidade com as políticas pombalinas relativas à educação e à economia. A ligação entre o autor e as propostas educacionais de Pombal já foram muito analisadas (cf. BOTO, 2017, p. 35-93). Procurei aqui evidenciar a afinidade entre as teses do médico português e a política econômica do ministro de D. José I. Política que se baseava "na intervenção estatal renovada, na estrutura empresarial, como também no mercado, no comércio e na produção tanto doméstica como colonial”, objetivando "desenvolver uma poderosa classe nacional de homens de negócios com recursos de capital e a habilidade comercial necessários para desafiar seus concorrentes estrangeiros" (MAXWELL, 1997, p. 170). É certo que várias sugestões de Sanches, como a reorganização da agricultura por meio de inspetores estatais e agentes camarários, nunca foram consideradas por Pombal e seus colaboradores. Mas a linha geral da política econômica do ministro parece encontrar inspiração em teses expressas pela "rede" de letrados da qual Ribeiro Sanches e Luís da Cunha faziam parte.

Insisto na importância da sobreposição entre essas "redes" de letrados portugueses e as "redes governativas" do Império. A correspondência de Sanches com o embaixador de Lisboa em Paris, Monsenhor Salema (LEMOS in SANCHES, 1922, p. VIII-X), é prova dessa relação. Em alguma medida, seus escritos estavam respondendo aos dilemas da elite imperial ou, ao menos, da parcela mais evolvida com os problemas internacionais. Segundo Cunha e Monteiro (in CARDIM; CUNHA; MONTEIRO, 2005, p. 217-231), essa elite, "mais especializada" e composta por membros da mais elevada nobreza, ocupava, de forma rotativa, os principais postos do Império sem se verificar seu "enraizamento local", ou seja, mantinha-se muito próxima do centro de decisão política da monarquia e estava atenta a seus interesses globais. Mesmo sem viver em Portugal, Sanches parece dialogar exatamente com esses grupos dirigentes que 
circulavam pela Europa e pelo Atlântico lusitano (FURTADO in FRAGOSO; GOUVÊA; 2014, p. 65-72). Em Paris ou na Holanda, ele pôde discutir com esses personagens, compartilhar suas angústias, estabelecer amizades duradouras, solicitar benesses ao rei e, em alguma medida, interferir na política portuguesa. Sendo assim, fica a pergunta: como um ilustrado tão crítico da fidalguia e do clero português podia ser aceito pelas "redes governativas"?

A resposta mais provável é que membros dessas "redes" concordavam com boa parte das críticas do autor ou, pelo menos, estavam dispostos a ouvi-las. A sensação generalizada, entre portugueses e estrangeiros, de que o Império estava "decadente" e sob forte ameaça de outras potências, pode ter estimulado a leitura dos escritos de Sanches. Afinal, ele estava tentando diagnosticar os principais fatores da decadência lusitana e oferecer propostas concretas para os problemas. Sanches, sem dúvida, atacava alguns dos "privilégios" de fidalgos que lideravam essas "redes", mas eles eram muito dependentes da coroa, ou seja, a manutenção e o desenvolvimento do Império eram vitais para todos eles. Para os mais lúcidos e bem-informados, era urgente mapear os problemas do Estado e respondê-los de maneira eficaz. A "história filosófica" da Luzes constituía, no século XVIII, um dos principais instrumentos intelectuais da elite europeia para pensar e avaliar a situação de suas sociedades. Os membros das "redes" que percorreram a Europa a serviço do rei sabiam disso. Mesmo sem visitar o estrangeiro era possível ter consciência do papel da "história filosófica" pelas publicações que chegavam, legal ou ilegalmente, em Portugal. Procurei mostrar que Sanches, ao investigar as origens da "monarquia gótica", oferecia uma interpretação tipicamente "filosófica" para a história de seu país natal. Ora, os membros mais esclarecidos das "redes", ansiosos por garantir a principal fonte de seu poder e riqueza, o Império, talvez estivessem dispostos a conhecer uma crítica que visava, justamente, aumentar a eficiência do Estado imperial. Até que ponto traduziram essa crítica em projetos efetivos de transformação social é tema para outro estudo.

\section{Referências}

ARAÚJO, A. C. llustração, pedagogia e ciência em António Nunes Ribeiro Sanches. Revista de história das ideias, v. 5, p. 377-394, 1984.

. Cultura da Luzes em Portugal. Lisboa: Livros Horizonte, 2003.

O Filósofo solitário e a esfera pública das Luzes. In: CRUZ et alii. Estudos em homenagem a Luís António de Oliveira Ramos. Porto: Universidade do Porto, 2004, v. I, p. 197-210.

BICALHO, M. F. As câmaras ultramarinas e o governo do Império. In: BICALHO, M. F.;

BLUTEAU, R. Vocabulario portuguuez e latino. Coimbra: Real Collegio das Artes da Companhia de Jesu, 1713, volume I.

ВОтО, C. Instrução pública e projeto civilizador. São Paulo: Editora da UNESP, 2017. 
CARDIM, P.; FELISMINO, D.; MONTEIRO, N. A diplomacia portuguesa no Antigo Regime: perfil sociológico e trajetórias. In: CARDIM, P.; CUNHA, M. S.; MONTEIRO, N. G. (orgs.). Optima pars. Elites ibero-americanas no Antigo Regime. Lisboa: Imprensa de Ciências Sociais, Universidade de Lisboa, 2005, p. 277-337.

CARNEIRO, A.; DIOGO, M. P.; SIMÕES, A. Enlightenment science in Portugal: The estrangeirados and their communication networks. Social Studies of Science, n. 30, p. 591-619, agosto, 2000.

CUNHA, M.; MONTEIRO, N. Governadores e capitães-mores do império atlântico português nos séculos XVII e XVII. In: CARDIM, P.; CUNHA, M. S.; MONTEIRO, N. G. (orgs.). Optima pars. Elites ibero-americanas no Antigo Regime. Lisboa: Imprensa de Ciências Sociais, Universidade de Lisboa, 2005, p. 191-252.

DULAC, Georges. Science et politique : les réseaux du Dr António Ribeiro Sanches(1699-1783). Cahiers du monde russe, v. 43, p. 251-274. 2002/2.

Deux réseaux au service de l'Académie des sciences de Saint Pétersbourg : autour de Ribeiro Sanches et de Johann Albrecht Euler. Dixhuitième siècle, $\mathrm{n}^{\circ} 40$, p. 193-210, 2008/1.

FURTADO, J. República de Mazombos: sedição, maçonaria e libertinagem numa perspectiva atlântica. In: RODRIGES, José Damião (org.). O Atlântico revolucionário: circulação de ideias e de elites no final do Antigo Regime. Lisboa: CHAM/Universidade Nova de Lisboa; Ponta Delgada: Universidade dos Açores, 2012, p. 291-321.

Dom João V e a década de 1720: novas perspectivas na ordenação do espaço mundial e as novas práticas letradas. In: FRAGOSO, J.; GOUVÊA, M. F. (orgs.). O Brasil colonial, 1720-1821. Rio de Janeiro: Civilização Brasileira, 2014, v. 3, p. 61-110.

FRAGOSO, J.; GOUVÊA, M. F. (orgs.). Na trama das redes: política e negócios no Império português, séculos XVI-XVIII. Rio de Janeiro: Civilização Brasileira, 2010, p. 155-202.

GOUVÊA, M. F. Redes governativas portuguesas e centralidades régias no mundo português. In: FRAGOSO, J.; GOUVEIA, M. F. (orgs.). O Antigo Regime nos trópicos: a dinâmica imperial portuguesa (séculos XVI-XVIII). Rio de Janeiro: Civilização Brasileira, 2001, p. 189-221.

HESPANHA, A. M. Às vésperas do Leviathan: instituições e poder político, Portugal, século XVII. Coimbra: Almedina, 1994.

ISRAEL, J. Iluminismo Radical: a filosofia e a construção da modernidade, 1650-1750. São Paulo: Madras, 2009.

LEFEBRE, G. A Revolução Francesa. São Paulo: IBRASA, 1989.

LEMOS, M. Ribeiro Sanches, sua vida e sua obra. Porto: Eduardo Tavares Martins, 1911. Notícia bibliográfica. In: SANCHES, A. N. R. Cartas sobre a educação da mocidade. Coimbra: Impressa da Universidade, 1922, p. V-XV.

MAXWELL, K. Marques de Pombal. Paradoxo do lluminismo. Rio de Janeiro: Paz e Terra, 1997. 
MIRANDA, T. C. R. "Estrangeirados: a questão do isolacionismo português nos séculos XVII e XVIII. Revista História, São Paulo, n. 123-124, p. 35-70, ago./jul., 1990/1991.

MONTEIRO, N. G. Elites e poder. Lisboa: Imprensa de Ciências Sociais, 2007.

MONTESQUIEU, Ch. De l'esprit de lois. Paris: Garnier, 1949, 2 volumes.

CASTRO, Z. O Estado e a Igreja. Pensamento de António Nunes Ribeiro Sanches. In: OSWALD, H.; RIBEIRO, J.; SILVA, F. (orgs.). Estudos em homenagem à Luís António de Oliveira Ramos. Porto: Universidade do Porto, 2004, p. 399-406.

RAMOS JR., N. Mediador das Luzes: concepções de progresso e ciência em Antônio Nunes Ribeiro Sanches. Dissertação (Mestrado em História Social) - Faculdade de Filosofia, Letras e Ciências Sociais, Universidade de São Paulo, São Paulo, 2013.

RAYNAL, G.-Th. Histoire phiosophique et politique des établissements et du commerce de européens dans les deux Indes. Genebra: Jean-Leonard Pellet, 1780, volume 1.

Histoire phiosophique et politique des établissements et du commerce de européens dans les deux Indes. Genebra: Jean-Leonard Pellet, 1780-1781, volume 5. SANCHES, A. N. R. Tratado de conservaçam e saude dos povos. Lisboa: Officina de Joseph Filippe, 1757.

1922.

. Cartas sobre a educação da mocidade. Coimbra: Impressa da Universidade,

Plan pour l'éducation d'um jeune seigneur russe. Manuscrito de Ribeiro Sanches (1766). Coimbra: Imprensa da Universidade de Coimbra, 2016.

. Dificuldades que tem um reino velho em emendar-se e outros textos. Organização Victor de Sá. Porto: Inova, s/d.

SILVA, A. R. C. Inventando a Nação. Intelectuais ilustrados e estadistas luso-brasileiros na crise do Antigo Regime português (1750-1822). São Paulo: Hucitex, 2006.

SUBTIL, J. Os desembargadores em Portugal. In: CARDIM, P.; CUNHA, M. S.; MONTEIRO, N. G. (orgs.) Optima pars. Elites ibero-americanas no Antigo Regime. Lisboa: Imprensa de Ciências Sociais, Universidade de Lisboa, 2005, p. 253-275.

59-69, 2011.

Pombal e o Rei: valimento ou governamentalização? Ler História, v. 60, p.

VENTURI, Franco. Utopia e reforma no lluminismo. Bauru: Edusc, 2003.

VOLTAIRE. Essai sur les moeurs et l'esprit des nations et sur les principaux faits de I'histoire depuis Charlemagne jusqu'à Louis XIII. Paris: Garnier Frères, 1963, 2 volumes. . Dictionnaire philosophique. Paris: Garnier-Flammarion, 1964.

. Oeuvres complètes. Paris: Garnier Frères, 1879. Reimpressão: Nendeln/ Liechtenstein: Kraus Reprint Limited, 1967, 50 volumes.

WEBER, Max. Economia e sociedade. Brasília: Editora UnB, 2009, vol. 2. 


\section{Notas}

1 Este artigo resulta de pesquisa de pós-doutorado realizada junto ao Departamento de História da Universidade Estadual de Campinas (UNICAMP) e supervisionada pela Profa. Iara Lis Franco Schiavinatto, a quem deixo meu agradecimento pelas preciosas sugestões e pelo apoio.

2 O termo "indústria", no século XVIII, nomeava as atividades artesanais e manufatureiras. Só mais tarde foi utilizado para definir especificamente o sistema de fábrica derivado da Revolução Industrial do final do século. Bluteau, no Vocabulário português latino, definiu "indústria" como "destreza em alguma arte", resgatando a origem latina da palavra (BLUTEAU, 1713, v. I, letra I, p. 116).

${ }^{3}$ Atualizei a grafia original.

Luiz Francisco Albuquerque de Miranda é professor doutor em Filosofia pela Universidade Estadual de Campinas (UNICAMP). ORCID: 0000-0001-8296-1822. Professor de História Moderna do Departamento de Ciências Sociais (DECIS) da Universidade Federal de São João del Rei (UFSJ), Campus Dom Bosco - R. Padre João Pimentel, 80, Dom Bosco, São João del Rei - MG, CEP: 36301-158. E-mail: Ifamiranda@ufsj.edu.br. 